6. Листи Шовкуненку О. О. Цибульника I. Додається список художників України членів Спілки художників з адресами. 4 квітня 1942 - 26 грудня 1945. Центральний державний архів-музей літератури і мистеитв Украӥни. Ф. 658. Оп. 1. Спр. 180. 13 арк.

7. Луганський обласний художній музей. Графіка. URL: http:// lugartmuseum.com/cat2a6c.htm?s42p182 (дата звернення: 10.07.2021).

8. Одеський художній музей. Каталог. Графіка, скульптура. Мистецтво, 1974. 288 с.

9. Сырлыбаева Г.Н. Крупнейшие выставочные проекты Союза художников Казахской ССР в годы Великой Отечественной войны. 1942-1943 гг. вторая Республиканская художественная выставка «Великая Отечественная война». 22 июня 1943 г. Алма-Ата. История. Память. Люди: Материаль VIII Междунар. науч.-практ. конф. (Алматы, 16 сентября 2016 г.). Алматы, 2017. С. 137-144.

10. Ткаченко [Шпак] В. Худяк Лев Матвійович. Художники Радянської України: у 4 т. Т. 4. Архів відділу образотворчого мистеитва ІМФЕ ім. М. Т. Рильського. С. 278-284.

11. Ходак I. Чотиритомний довідник «Художники Радянської України»: концепція, історія підготовки, автори маловідомого академічного проекту 1940-1950-х років. Збірник наукових студій пам'яті докторки мистецтвознавства Валентини Рубан. НАН України, ІМФЕ ім. М. Т. Рильського. Київ, 2019. С. 325-383.

DOI https://doi.org/10.30525/978-9934-26-117-6-37

\title{
ХУДОЖНЬО-ЕСТЕТИЧНІ ЗАСАДИ \\ АРТ-ОБ'СДНАННЯ «БУРИМЕ» (ДО 30-РІЧНОГО ЮВІЛЕЮ ТВОРЧОГО ТОВАРИСТВА)
}

\author{
Найденко В. О. \\ аспірантка кафедри теорії $і$ історії мистецтвв \\ Харківська державна академія дизайну і мистечтв \\ м. Харків, Украӥна
}

Здобуття Україною незалежності сприяло змінам у мистецькому процесі міста, спричинило вихід із андеграунду культурних пластів, що підпільно існували за часів радянської влади. Нове покоління мистців бажали об'єднуватися у неформальні арт-об'єднання та переоцінювати сучасну дійсність. Художники прагнули відійти соцреалістичного 
оповідально-подійного мистецтва до філософсько-поетичних шукань та нової образності. Зокрема, в харківському образотворчому середовищі з'являється ряд об'єднань: «Харківська група», «Колір мистецтва», «Літера А», «Арт-Бат», «Істинні художники», «Незалежна студія», «Red horse», «Оксюморон», та «Буриме». Більших 3 цих угрупувань виявилися хисткими, не витримавши перепитій «лихих 90-х», закінчивши своє існування на самому початку. Проте творче об'єднання «Слобожанське буриме» стійко витримує всі коливання долі та цього року святкує своє 30-річчя, гордо несучи статус однієї 3 найстарших мистецьких товариств.

Учасники арт-угруповання «Буриме» свій відлік починають з 1991 року, коли пройшла їх перша спільна виставка в Будинку художника. Проте історія їх співпраці починається раніше. На початку 90 -х популярним стає пленерний живопис, до якого долучився художник-дизайнер Олександр Шеховцов. Згодом до нього приєдналися дизайнери та архітектори харківської філії ВНДІТЕ, випускники Харківського художньо-промислового інституту (нині ХДАДМ) та архітектурного факультету Харківського інженерно-будівельного інституту (нині Харківський національний університет будівництва та архітектури). Спільна пленерна діяльність, групові літні подорожі та виставки посприяли об'єднанню однодумців у творче угруповання.

Спочатку група мала назву «Слобожанське буриме», зосередивши біля себе низку мистців, зокрема Володимира Голенищева, Володимира Ландкофа, Олександра Лисенко, Якова Пундика, Олександра Шеховцова, Олександра Шила, Олександра Юхтмана. Потім вкоротилася не тільки назва групи до «Буриме», але й зменшився ії склад. Нині ядро угруповання складають четверо: Олег Лазаренко, Олександр Шеховцов, Валентин Грицаненко та Олександр Лисенко.

Метафорична назва мистецького об'єднання бере свій початок із Франції та відсилає нас до часів Людовика XIV. Слово «буриме» походить від французького bouts-rimes, що дослівно перекладається як «римовані кінці» та ознаменовує літературну гру, яка полягає у складанні віршів, частіше жартівливих, на задані рими, часом і на задану тему. Як зазначає Г. Гаврилів, «гра буриме передбачає збереження кожним учасником індивідуальної манери та стилю. Мистці також бачили основним принципом своєї творчості обов'язкове збереження власного живописного стилю, манери, художніх орієнтацій і смаків» [1, с. 87].

Джерелом енергії та натхнення для «буримістів» слугують мандрівки та пленери, які спонукають до освоєння небачених країв, відкривають нові горизонти для творчості та сприяють переосмисленню «застарівших» бачень. Як зазначає О.Шеховцов в інтерв'ю газеті 
«Вечірній Харків», «пленери - це цементуючий матеріал наших відносин. Подібні поїздки дуже зближують, там взаємини зовсім інші, та й розмови виключно про мистецтво» [3].

Географія місць, куди художники виїжджають на пленери, охоплює численні куточки нашої планети. Результатом цих подорожей стала низка проєктів, які вражають своєю масштабністю. Найзначимий проєкт творчого товариства «Цивілізація любові» - унікальний цикл картин, започаткований наприкінці 1990-х років. Кожна картина має гігантський розмір $(3 \times 3$ або $4 \times 1,5)$, спонукаючи глядача схилитися перед iї монументальною величчю. Особливість проекту в тому, що кожен художник на полотні зумів зберегти власний стиль і манеру письма: постмодерн, плюс авангард, плюс реалізм - вийшла справжня гримуча суміш, яка не має аналогів в історії мистецтва.

Кожний витвір «Цивілізації любові» уособлює принципи самопожертви, гуманності, абсолюту, любові та братства. Поштовхом до формування загальної концепції став вислів Папи Римського Івана Павла II про майбутне земної цивілізації у вимірах християнської етики і християнської любові [1, с. 88]. «Буримістична «Цивілізація любові»»» нагадує Андрєєвську «Троянду світу» («Роза Мира»), яка прагне об'єднати світ воєдино, щоб уникнути повторення страшних історичних подій та встановити мир у всьому планетарному космосі.

На полотнах мистців розгортаються важливі сенсобуттєві теми, висвітлюються моральні проблеми, оголюються питання про суть духовності в цифорову епоху, про екзистенційний криз сучасної людини. Мистці діалогізують з нами на ці теми за допомогою ряду символів, які пов'язані з древніми цивілізаціями та біблійською тематикою. Кожний витвір творчого угрупування глибоко філософський, сакраментальний, метафоричний, гіпертекстуальний, проте доступний для розуміння пересічним глядачем.

Образотворча мова «буримістів» строката, проте не позбавлена гармонії. За словами Л.Стародубцевої, «перед нами - те, що в поетиці називається грецьким словом «оксюморон»:поєднання непоєднуваного. В філософії це називається «збігом протиріч...» [4, с.75]. Особливістю ïx письма $\epsilon$ ідея взаємонашарування зі збереженням стилістики кожного автора. Зокрема, художня манера О.Шеховцова близька до ташизму та імпресіонізму; В. Грицаненко поетизує та ідеалізує безкраї простори, які відтворює у гіперреалістичній манері; О. Лисенко звертається до образів та архетипів сільської архаїки; О. Лазаренко вирізняється мозаїстичною технікою живопису.

Особливістю «буримістів»є їхнє проектно-образне мислення,яке продиктоване дизайнерською освітою. Приступаючи до творення 
мистці не мають перед очима готової композиції. Вона у них виступає як сам процес, результат якого не можна передбачити.

Участь у дизайнерських проектах сприяла подальшій колективній со-творчій праці «Буриме», де без консенсусу та злагодженості неможливо реалізовувати задумане. На думку О. Лазаренка, дизайнерський дух спонукає художників до вічних пошуків та експериментів 3 матеріалами, техніками, форматами тощо, адже постійний науковотехнічний прогрес сприяє розвитку дизайну, тому там чіткий контроль за плагіатом [2].

Парадигма со-творчої діяльності арт-об’єднання «Буриме», за свідченням учасників групи, базується на вангогівській концепції згуртування кількох мистців задля «втілення в життя загальної ідеї» творення вищого синергетичного мистецтва. Ван Гог в одному з листів висловив думку про можливість спільного живописного письма кількох художників на одному полотні. «Буримісти» утопічну ідею великого постімпресіоніста втілили в життя, продемонструвавши тим самим свій відважний дух та високі моральні якості. Учасники угруповання попри періодичні розбіжності, вже ж знаходять «золоту» середину у колективній творчості, гармонізують особистісні техніки з іншими манерами письма мистців-буримістів.

Отже, творче об'єднання «Буриме» вже понад чверть століття веде бурхливу мистецьку діяльність. За словами Г.Гаврилів, вони втілюють «своєрідну модель слобожанського постмодернізму» [1, с. 93]. Со-творча робота мистців, застосовування принципів кола жування та нашарування, постійна гра та вихід за рамки художнього полотна робить ї органічною частиною сучасного художнього простору. А звернення «буримістів» до «вічних тем», втілення ідей гуманізму та любові на їх полотнах говорить про їх стремління до духовного прозріння.

\section{Література:}

1. Гаврилів Г. М. Харківська мистецька група «Буриме»: філософсько-естетичний аспект. Вісник ХДАДМ. 2017. № 3. С. 85-93.

2. Найденко В.О. Інтерв'ю художником Олегом Лазаренком. Харків, 2021. 30 червня. 2 с.

3. Осінчук М. Феномен «Слобожанського Буриме». Вечірній Харків. 20.07.2005. URL: http://vecherniy.kharkov.ua/news/58/ (дата звернення: 18.06.2021).

4. Яновский В.Н. «Буриме»:Утопия Ван Гога. Монография / Сост.,подгот. текстов и предисл. Л.В.Стародубцевой; под общ. ред. Н.Ф.Колосовой. Харьков, 2008. 542 с. 